\title{
Relationship Marketing for B2B Indihome Consumer Loyalty
}

\author{
Dwi Fitrizal Salim ${ }^{1, *}$ Ratih Hurriyati ${ }^{2,}$ Mokh. Adib Sultan ${ }^{3}$ \\ ${ }^{1}$ Universitas Pendidikan Indonesia \\ ${ }^{2}$ Universitas Pendidikan Indonesia \\ ${ }^{3}$ Universitas Pendidikan Indonesia \\ *Corresponding author.Email: dwifitrizal11@gmail.com
}

\begin{abstract}
Today's era of globalization must change marketing management from traditional marketing to relationship marketing by maintaining good relationships with customers so that customers will be loyal to the products/services that have been made. Many studies discuss relationship marketing in Business to Business B2B (Zimmerman and Blythe, 2013). The essential factors in $\mathrm{B} 2 \mathrm{~B}$ relationships and success are maintaining relationships with customers on an ongoing basis to create customer loyalty (Ross, Caning, and Mcdowell, 2004). Customers from B2B consider in terms of efficiency and relatively lower prices from suppliers of products or services. Doma (2013) maintains a harmonious relationship and service quality between suppliers and consumers. B2B is the power of the company to business partners is power. Jain et al (2014), Martadisatra (2017), Setyawan (2014). This study took a sample of B2B customers at the company PT. Telekomunikasi Indonesia which has Indihome product services. The sample will be collected through 100 respondents and will be tested by simple regression. The results of the study's discussion show that there is a significant effect of Relationship Marketing on B2B indihome consumer loyalty by R Square 55\%, indicating that loyalty affects 55\% of Indihome B2B consumer loyalty. This study also conducts a t-test and has the value of $\mathrm{t}$ count of $11.065>\mathrm{T}$ table 1.984 . This shows that the variable $\mathrm{X}$ relationship marketing influences the $\mathrm{Y}$ Loyalty variable. The significance level is 0.00 $<0.05$ significant value, which means that the $\mathrm{X}$ relationship variable marketing significantly affects $\mathrm{Y}$ Loyalty variables.
\end{abstract}

Keywords: Business to Business (B2B), Marketing Relationships.

\section{INTRODUCTION}

In marketing relationships with customers, it is essential for the business to grow or run the material or subject matter consistently in marketing Business to Business (B2B). B2B is a business that is carried out with the target market of a corporation. Several factors affect the market, such as economic, legal, social, and technological factors and the trend of globalization, which makes a market dynamic and challenging to predict [1]. B2B can be done on domestic and international markets, such as a company goods/services can be used alone by the organization or resold to other organizations or consumers in need. $40 \%$ of B2B transactions occur both domestically and internationally (Ross, Caning, and Mcdowell, 2004). Customers from B2B consider in terms of efficiency and prices that are relatively cheaper than suppliers of products or services.
In terms of B2B customers themselves, according to [2], it has complexity in decision making where many internal customers are directly or indirectly involved in decision making, so that marketers must be able to identify who occupies that position and then try to establish an effective relationship.

Reference [3], companies can manage good relationships with customers by making strategic plans supported by good corporate performance. The company pays attention to the traditional relationship with the customer and must place the customer as the key to creating customer satisfaction and loyalty.

Reference [4] The purpose of exchanges, the characteristics of communication, organizational goals, managerial focus, managerial investment, are factors that become the research material of several researchers in the marketing of Business to Business B2B in order to create 
long relationships with customers to create a sense of satisfaction and loyalty for customers.

The research was conducted in Taiwan in the steel industry, service quality, and customer satisfaction on the B2B market directly related to or influenced consumer loyalty. In contrast, service quality does not directly affect consumer loyalty, where customer satisfaction is an intermediate variable. Service quality is a significant factor affecting satisfaction consumers in the steel industry [5].

One sustainable competitive advantage is building harmonious relationships between suppliers and customers for a long time. Research of [6] outlines the most critical factors in relationships, and B2B's success is to maintain relationships with customers on an ongoing basis to create loyalty with customers. Reference [7] maintains a harmonious relationship, and service quality between suppliers and consumers is an essential key in B2B success to generate customer loyalty. Subsequent research carried out in Yogyakarta regarding the decision to purchase airplane tickets at the Total Nusa Indonesia tour and travel obtained results from the marketing mix $\mathrm{F}$ Test, which affected the decision to purchase airline tickets at PT Total Nusa Indonesia tour and travel [8].

There is a positive and significant relationship between customer perceived quality on relationship quality both partially and simultaneously, where the higher the quality of service, the higher the level of relationship with customers. Then there is a positive influence between relationship quality on business loyalty. This shows that the better the partnership satisfaction relationship's quality, the higher the level of loyalty, [9]. This research examines the factors that influence customer decisions in purchasing Air Asia flight tickets online, bringing out the results that factors affecting flight ticket purchases include: intelligence, design, choice, cost-saving, and time-saving, which have a positive effect on satisfaction, [10].

There is a relationship between relationship marketing, power, and loyalty in Indonesia's industry, especially retailers and suppliers. An essential problem in $\mathrm{B} 2 \mathrm{~B}$ business is power, which is the company's power to its business partners. [11-13], in a B2B business, the process of bargaining for business must be emphasized towards their business partners. The manufacturing industry that acts as a supplier for the retail industry also occurs in the oligopoly market because of differences in the inability to survive in competitive markets. Companies that cannot compete are usually small companies and new business players [14].

This research will discuss at PT. Telekomunikasi Indonesia (Persero) performance grew positively. The main driver is Business to Business (B2B) service, noncellular business performance owned by PT. Telkom Group with subsidiaries owned such as Indihome,
Telkomsigma, and Telomtelstra. Indihome itself has a growth of up to $50 \%$, Business to Business conducted by PT. Telkom collaborates with corporations, SMIs, ministries, regional governments, TNI / POLRI, and other institutions. Indihome service also anticipates a number of disruptions that will disappoint customers, so that it decreases the loyalty level of individual services. To overcome this problem, Indihome has provided 147 call center services and Telkom plasa. It even has MyIndihome apps that can be accessed via the web or applications on individual mobile phones without queuing on the Telkom plaza or called 147 call center. The research discussed the relationship between Business to Business B2B both in Indonesia and abroad.

Relationship marketing is a concept where it is crucial for companies to attract and retain customers in an organization. In the era of globalization, companies must change from traditional marketing to relationship marketing by choosing good relationships with customers so that customers will be loyal to the products/services that have been made, [4]. A loyalty program that gives PT. Telkom Padang City has no significant effect on speedy Customer Loyalty PT. Telkom, [15]. By considering this research's phenomena, there is nothing that discusses relationship marketing to Indihome Consumer Loyalty, so this study takes the Title of Research "Relationship Marketing for B2B Indihome Consumer Loyalty". Based on the research background, this study's research questions are as follows: How is the relationship marketing relationship to $\mathrm{B} 2 \mathrm{~B}$ Indihome customer loyalty?

The purpose of this study is as follows: To find out the influence of relationship marketing B2B Indihome customer loyalty.

\section{METHODS}

\subsection{Relationship marketing}

Relationship marketing is one of the company's strategies to meet customer needs and desires. From the customer's point of view, we will find the factors of trust, commitment, mutuality, and long-term relationships, [16].

\subsection{Loyalty}

Loyalty is the result of customer satisfaction with the services provided, and it is a service that is good and able to meet the needs and desires of customers is a form of a long-term relationship between the company and customers that have an impact on improving the company performance [17].

\subsection{Research framework}

Show the research framework. 


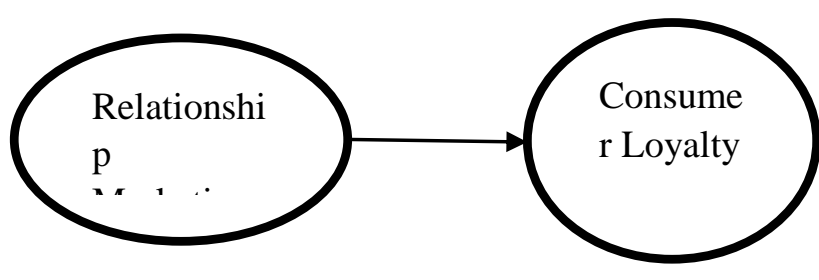

Figure 1. Research framework

The framework will be tested by testing the relationship between Relationship Marketing on Consumer Loyalty. The notion which is saying that relationship marketing affects consumer loyalties is widely researched both in Indonesia and abroad such as $[9,18,5,19,4,14$. $]$ Since many studies have examined the variable relationship marketing to loyalty, this study will examine consumers in $\mathrm{B} 2 \mathrm{~B}$ businesses on Indihome products. The data is taken through the question that will be distributed to individual customers. The population is all Indihome customers. The sample used by a group of Indohome employees partners where the individual itself for B2B business also targeted BUMN / Government employees to launch a government movement, namely synergy BUMN.

This research belongs to quantitative research because the data used is in the form of a questionnaire that will be interpreted in the form of numbers and tested using the SPSS 22 application and measured the significance of the effect between variables relationship marketing and consumer loyalty variables.

Questionnaires were tested for validity, aiming to show the accuracy of the data obtained by researchers with actual data so that validity must be sought. Furthermore, the data will be tested with a Reliability Test that aims to what extent the test is carried out many times against the same object to get consistent results. Furthermore, a normality test will be conducted aimed to find out whether the data taken has the value of the distribution of data in a group of variables with normal distribution or not. Finally, a simple regression with TTest was done by testing the significant level between Variable relationship marketing with consumer loyalty Variable. Then, this study analyzed whether the variable business to business has a significant effect on the consumer loyalty variable or not.

\section{Hypothesis}

The hypotheses that will be tested in this study are as follows:

$\mathrm{H} 0$ : There is no effect of relationship marketing on individual customer loyalty

$\mathrm{H1}$ : There is an influence of relationship marketing on indihome customer loyalty.
This study will examine the influence of the independent variable (relationship marketing) on the dependent variable (Indihome customer loyalty). The relationship marketing consisted of understanding customer expectations, building service partnerships, and total quality management. This study uses a simple regression where the variable relationship marketing marketing will affect the variable consumer loyalty Indihome customer loyalty. Simple regression tests between variables in regression analysis are causal or causal.

\section{RESULTS AND DISCUSSION}

The study examined the questionnaires that have been distributed to 100 respondents by conducting a series of tests, such as:

\subsection{Validity and Reliability Test}

This validity test aims to see whether the questionnaire distributed to respondents has a standard measure of the accuracy of a research instrument so that the measurement results are under the research objectives. The value of the R-table with N 100 with a significance level of $5 \%$ is seen in the table of 0.195

If $\mathrm{R}$ count $>\mathrm{R}$ Table $=$ valid

If $\mathrm{R}$ Count $<\mathrm{R}$ Table $=$ invalid

The results obtained that all items in question as many as 23 questions, including variables business to business and consumer loyalty, have valid results, for the results of the calculation of the validity test can be seen in appendix 1 .

The reliability test aims to determine the level of consistency. The more consistent the results of these measurements, the more reliable the results, and vice versa. The results of the reliability testing in this study can be seen in Table 1 .

Table 1. Reliability statistics

\begin{tabular}{|l|l|l|}
\hline $\begin{array}{l}\text { Cronbac } \\
\text { h's Alpha }\end{array}$ & $\begin{array}{l}\text { Cronbach's } \\
\text { Alpha Based on } \\
\text { Standardized } \\
\text { Items }\end{array}$ & $\begin{array}{l}\text { N of } \\
\text { Items }\end{array}$ \\
\hline .961 & .962 & 23 \\
\hline
\end{tabular}

From table 3.1, the value of Cronbach's Alpha is $0.962>0.6$, indicating that the questionnaire is reliable. 
The normality test aims to assess the distribution of data in a group or population, whether it has a normal distribution or not, and is useful to determine that the data has been normally distributed or taken from a normal population. The results of the normality test can be seen in Table 2.

Table 2. Normality test

\begin{tabular}{|c|c|c|}
\hline & & $\begin{array}{l}\text { Unstandardized } \\
\text { ed Residual }\end{array}$ \\
\hline $\mathrm{N}$ & & 100 \\
\hline Normal & Mean & .0000000 \\
\hline Parameters a,b & $\begin{array}{l}\text { Std. } \\
\text { Deviation }\end{array}$ & 2.72821150 \\
\hline Most Extreme & Absolute & .084 \\
\hline Dinerences & Positive & .068 \\
\hline & Negative & -.084 \\
\hline Test Statistic & & .084 \\
\hline Asymp. Sig. (2 & & $.080 \mathrm{c}$ \\
\hline a. Test distribut & s Normal. & \\
\hline b. Calculated fr & lata. & \\
\hline c. Lilliefors $\mathrm{Si}$ & ce Cor & ion. \\
\hline
\end{tabular}

Source : data processed

\subsubsection{Test $T$}

Based on Table 3, the results of the correlation value / $\mathrm{R}$ relationship are 0.745 . Then from the output, the coefficient is terminated equal to 0.555 , which means that the influence of independent variables (relationship marketing) on the dependent variable (Loyalty) is $55 \%$.

\subsection{2. $r$ square}

Table 3 The results of the correlation value

\begin{tabular}{|l|l|l|l|l|}
\hline Model & $\mathbf{R}$ & $\begin{array}{l}\text { R } \\
\text { Square }\end{array}$ & $\begin{array}{l}\text { Adjusted } \\
\text { R } \\
\text { Square }\end{array}$ & $\begin{array}{l}\text { Std. } \\
\text { Error of } \\
\text { the } \\
\text { Estimate }\end{array}$ \\
\hline 1 & $.745 \mathrm{a}$ & .555 & .551 & 2.74210 \\
\hline $\begin{array}{l}\text { a. Predictors: (Constant), Relationship } \\
\text { Marketing }\end{array}$ \\
\hline \multicolumn{2}{|l}{ b. Dependent Variable: Loyalty } \\
\hline
\end{tabular}

Table 4. Show the result of a simple regression.

\begin{tabular}{|c|c|c|c|c|c|c|}
\hline \multirow{2}{*}{\multicolumn{2}{|c|}{ Model }} & \multicolumn{2}{|c|}{$\begin{array}{l}\text { Unstandardiz } \\
\text { ed } \\
\text { Coefficient }\end{array}$} & \multirow{2}{*}{$\begin{array}{l}\text { Standard } \\
\text { ized } \\
\text { Coefficie } \\
\text { nts } \\
\text { Beta }\end{array}$} & \multirow[t]{2}{*}{$\mathbf{t}$} & \multirow[t]{2}{*}{ Sig. } \\
\hline & & B & $\begin{array}{l}\text { Std } \\
\text { Error }\end{array}$ & & & \\
\hline \multirow[t]{2}{*}{1} & (constat) & $\begin{array}{l}7,2 \\
60\end{array}$ & 2,046 & \multirow[b]{2}{*}{.745} & $\begin{array}{l}3.54 \\
9\end{array}$ & $\begin{array}{l}.00 \\
1\end{array}$ \\
\hline & $\begin{array}{l}\text { Relation } \\
\text { ship } \\
\text { Marketin } \\
\text { g }\end{array}$ & $\begin{array}{l}.21 \\
8\end{array}$ & .020 & & $\begin{array}{l}11.0 \\
65\end{array}$ & $\begin{array}{l}.00 \\
0\end{array}$ \\
\hline
\end{tabular}

a. Depemdent variable : Loyalty

source: data processed

Based on Table 4 the results of a simple regression equation (1) are as follows:

$\mathrm{Y}=\mathrm{a}+\mathrm{bX}$

$\mathrm{Y}=7.260+0.218 \mathrm{x}$

From the regression results above, it can be concluded that:

- Constant variables have a participation value of 7.260

- The regression coefficient $\mathrm{X}$ of 0.218 means that every change of $1 \%$ variable $\mathrm{X}$ relationship marketing has increased participation 0.218. the regression coefficient is positive. Then the results have the effect of variable $\mathrm{X}$ on $\mathrm{Y}$ positive.

- Based on the significance value obtained by the coefficient results obtained at $0.00<0.05$, it can be concluded that relationship marketing influences Loyalty.

- To determine the value of t equation (2) are as follow:

$\mathrm{T}$ table $=(\mathrm{a} / 2: \mathrm{n}-\mathrm{k}-1)$

$(0.50 / 2: 100-1-1)=(0,025: 98)$

Then the result of $\mathrm{t}$ table is 1,984

Based on the value of $t$, it is known that the value of $t$ count is $11,065>\mathrm{T}$ table 1,984. This shows that the variable $\mathrm{X}$ relationship marketing influences the $\mathrm{Y}$ Loyalty variable

\section{CONCLUSIONS}

The results show a significant effect of Relationship Marketing on B2B indihome consumer loyalty of $\mathrm{R}$ Square $55 \%$, which indicates that loyalty affects $55 \%$ of Indihome B2B consumer loyalty. This study also conducts a t-test and has the value of $t$ count of 11.065> $\mathrm{T}$ table 1.984. This shows that the variable $\mathrm{X}$ relationship 
marketing influences $\mathrm{Y}$ Loyalty variables. The significance level is $0.00<0.05$ significant value, which means that the $\mathrm{X}$ relationship variable marketing influences Y Loyalty variables.

Overall, Indihome must continue to maintain relationship marketing for each of its consumers, both Business to Business (B2B) consumers and end consumers, by establishing good relations. Thus, Indihome will get more benefits, such as loyal customers and customers will recommend to relatives and friends to use Indihome services. However, that alone is not enough. Indihome must always maintain the other dimensions in relationship marketing, such as understanding customer expectations, empowering employees, total quality management, and dan building service partnerships.

\subsection{Recommendations}

\subsubsection{Future research}

Can look for factors that influence loyalty, such as Emotional Bonding, Trust, Choice reduction, and habit and History with a company (experience with the company). For companies that will be studied, such as companies providing goods, services, and online stores (E-Commerce)

\subsubsection{Company}

Input for the company PT. Telekomunikasi Indonesia (Persero), which has Indihome products, must pay attention to the variable factors studied in this study, such as understanding customer expectation, empowering employees, total quality management, and building service partnerships.

\section{REFERENCES}

[1] E. Turban, D. King, J. K. Lee, T.-P. Liang, and D. Turban, Electronic Commerce: a Managerial and social Networks Perspective 2015.

[2] P. Kotler, W. Pfoertsch, and I. Michi, B2B brand management. 2006.

[3] N.E. Coviello, R.J. Brodie, P.J. Danaher, and W.J. Johnston, "How firms relate to their markets: An empirical examination of contemporary marketing practices," J. Mark., vol. 66, no. 3, pp. 33-46, 2002.

[4] S. Sivesan, "Service quality and customer satisfaction: a case study -banking sectors in Jaffna District, Sri Lanka," Int. J. Mark. Financ. Serv. Manag. Res., 2012.

[5] K. Liao, "Service quality, and customer satisfaction: direct and indirect effects in a B2B customer loyalty framework," J. Glob. Bus. Manag., 2012.

[6] Zimmerman and J. Blythe, Business to Business Marketing Management. Third Avenue, New York, Routledge: Routledge, 2013.

[7] S.B. Ahmed, "Relationship quality as predictor of B2B customer loyalty," in WMSCI 2011 - The 15th World Multi-Conference on Systemics, Cybernetics and Informatics, Proceedings, 2011.

[8] P. H. H. Duari, "Pengaruh bauran pemasaran terhadapkeputusan membeli tiket pesawat di total nusa indonesia tour and travel Yogyakarta," J. media wisata, 2014.

[9] K.S. Yee, “Customer perceived quality, relationship quality, and business loyalty: an example of B2B organization," University of Malaya., 2008.

[10]B. Sudrajat, “Analisis faktor-faktor yang mempengaruhi kepuasan pelanggan terhadap pembelian tiket pesawat secara online di situs Air Asia," Ph.D. dissertation, Universitas Indonesia, Jakarta, 2012.

[11]M. Jain, S. Khalil, W.J. Johnston, and J.M.S. Cheng, "The performance implications of powertrust relationship: The moderating role of commitment in the supplier-retailer relationship," Ind. Mark. Manag., 2014.

[12] D.S. Martadisastra, "Kinerja pemasok dalam rantai pasokan makanan kemasan: suatu kajian kasus di Indonesia,’ J. Bisnis dan Manaj. Kompetensi, 2017.

[13] Setyawan, "Pengaruh power asymmetry \& relationship marketing pada kinerja strategis perusahaan dalam hubungan bisnis antara pemasok \& peritel," Ph.D. dissertation, Universitas Gadjah Mada, Yogyakarta, 2014.

[14] Y. Kurniati, and Yanfitri, Dinamika Industri Manufaktur dan Respon Terhadap Siklus Bisnis. 2010.

[15] T.I. Indrayani, "pengaruh relationship marketing terhadap loyalitas pelanggan speedy PT. Telekomunikasi Indonesia (Telkom), Tbk Kandatel Sumbar," J. Benefita, 2016.

[16]T. Velnampy and S. Sivesan, "Customer relationship marketing and customer satisfaction: a study on mobile service providing companies in Sri Lanka,” Glob. J. Manag. Bus. Res., 2012.

[17]P. Rauyruen and K.E. Miller, "Relationship quality as a predictor of B2B customer loyalty," J. Bus. Res., 2007.

[18] S.Y. Lam, V. Shankar, M.K. Erramilli, and B. Murthy, "Customer value, satisfaction, loyalty, and 
switching costs: An illustration from a business-tobusiness service context," J. of the Academy of Marketing Science. 2004.

[19] Tonton, and O. Gyamfi, "Maintaining customer relationship in b2b market," Ph.D Tdissertation, Business Administration, Jonkoping International Business School, Jönköping, Swedia, 2006. 